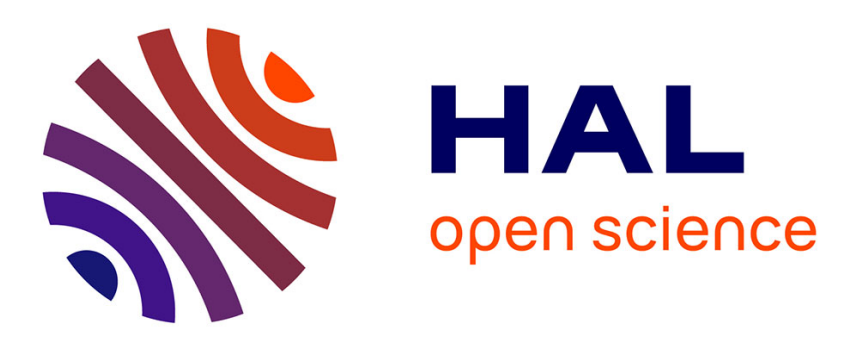

\title{
Anti-predator behaviour in a procellariid seabird: Wedge-tailed shearwaters do not respond to the odour of introduced ship rats
}

\author{
A. Gérard, H. Jourdan, A. Millon, E. Vidal
}

\section{- To cite this version:}

A. Gérard, H. Jourdan, A. Millon, E. Vidal. Anti-predator behaviour in a procellariid seabird: Wedgetailed shearwaters do not respond to the odour of introduced ship rats. Austral Ecology, 2015, 40 (7), pp.775 - 781. 10.1111/aec.12252 . hal-03559059

\section{HAL Id: hal-03559059 \\ https://hal-amu.archives-ouvertes.fr/hal-03559059}

Submitted on 5 Feb 2022

HAL is a multi-disciplinary open access archive for the deposit and dissemination of scientific research documents, whether they are published or not. The documents may come from teaching and research institutions in France or abroad, or from public or private research centers.
L'archive ouverte pluridisciplinaire HAL, est destinée au dépôt et à la diffusion de documents scientifiques de niveau recherche, publiés ou non, émanant des établissements d'enseignement et de recherche français ou étrangers, des laboratoires publics ou privés. 


\title{
Anti-predator behaviour in a procellariid seabird: Wedge-tailed shearwaters do not respond to the odour of introduced ship rats
}

\author{
A. GÉRARD, ${ }^{1, \star}$ H. JOURDAN,${ }^{1}$ A. MILLON ${ }^{2}$ AND E. VIDAL ${ }^{1}$ \\ ${ }^{1}$ Institut Méditerranéen de Biodiversité et d'Écologie marine et continentale (IMBE), Aix-Marseille \\ Université, UMR CNRS - IRD - UAPV, Centre IRD de Nouméa, BP A5, 98848 Nouméa Cedex, \\ Nouvelle-Calédonie, France (Email: agathe.gerard@ird.fr), and ${ }^{2}$ Institut Méditerranéen de Biodiversité \\ et d'Écologie marine et continentale (IMBE), Aix-Marseille Université, UMR CNRS - IRD - UAPV, \\ Europôle de l'Arbois, Aix-en-Provence, France
}

\begin{abstract}
Seabirds are particularly vulnerable to introduced alien mammalian predators, especially invasive rats, which are the main contributors to seabird extinction and endangerment in many places worldwide. However, this appears context-dependent because, paradoxically, cases of apparent long-term coexistence between rats and some species of seabird have been reported for centuries, in various locations. Among seabirds, procellariiforms are known to have developed a range of olfactory-driven behaviours, such as partner recognition and homing. Olfaction could be an effective means of recognizing and thereafter avoiding invasive predators. However, the role of olfaction in predation risk assessment has not yet been examined in any procellariiform. Here, we investigated, through a Y-maze experiment, whether the wedge-tailed shearwater (Puffinus pacificus) avoided the odour of one of the most damaging alien predators on islands, the ship rat (Rattus rattus). The experiment was conducted in different ecological contexts on three neighbouring islets off New Caledonia having different communities of invasive rats. Contrary to our expectations, the wedge-tailed shearwater either did not detect or did not avoid the odour of the ship rat, despite about 175 years of coexistence between rats and shearwaters in New Caledonia. These findings highlight the need for further investigations (across species, across sites) into the factors underpinning the paradox between high vulnerability and the surprising long-term coexistence between procellariid seabirds and alien invasive rats.
\end{abstract}

Key words: avoidance behaviour, introduced rodent, invasive species, Procellariiformes, Y-maze experiment.

\section{INTRODUCTION}

Introduced mammals, especially predators, are known to have severely impacted island birds worldwide, including seabird species (e.g. Owens \& Bennett 2000; Courchamp et al. 2003; Hervias et al. 2013; Spatz et al. 2014). Rats (Rattus sp.) in particular have colonized about $90 \%$ of the world's islands (Atkinson 1985; Towns et al. 2006) and are among the main contributors to seabird extinction and endangerment documented worldwide, particularly for small- to medium-sized procellariid seabirds such as petrels and shearwaters (Jones et al. 2008; Shiels et al. 2014). The vulnerability of petrels and shearwaters to invasive rats is enhanced by their ground- or burrow-nesting habits, which make the eggs, chicks and incubating adults easy prey (e.g. Warham 1996; Jones et al. 2008). Like many species having evolved in the absence of predators on isolated islands, petrels and shearwaters gen-

${ }^{\star}$ Corresponding author.

Accepted for publication March 2015. erally exhibit no or ineffective anti-predator behaviour when facing alien predators (Warham 1996; Carthey \& Banks 2014).

Nevertheless, several cases of apparent long-term coexistence between rats and seabirds have been reported on many islands around the world (Catry et al. 2007; Quillfeldt et al. 2008; Ruffino et al. 2009). These paradoxical situations suggest that the impact of rats on seabirds could be context dependent, that is, may vary according to the period when seabirds are available as prey (returning to the land) and to the availability of alternative food resources during the year (Rayner et al. 2007). Alternatively, some seabirds may sometimes manage to chase away rats through aggression or nest defence behaviour (Warham 1996). Procellariid seabirds may also have locally developed indirect, cryptic anti-predator behaviours so as to reduce the impact of rats (e.g. Ruffino et al. 2009; Bourgeois et al. 2013). Interestingly, the extent and the rapidity of some seabird population recovery after rat eradication (Bourgeois et al. 2013) suggest that rats had previously prevented birds from breeding, and points to an as yet unidentified behavioural process 
enabling shearwaters to detect and avoid rat-infested islands, and to rapidly (re)colonize islands when rats are removed.

The use of olfaction to assess predation risk is common across species of vertebrates (Kats \& Dill 1998), and it has recently been suggested that olfaction and chemical communication in birds may be more important than previously thought (Steiger et al. 2008; Bonadonna \& Mardon 2013). Procellariid seabirds in particular use chemical communication and their sense of smell for many purposes, including identification of foraging areas (Nevitt 2000; Nevitt \& Bonadonna 2005), homing and nest recognition (Bonadonna et al. 2003a,b; Bonadonna et al. 2004), or partner recognition (Bonadonna \& Nevitt 2004). The ability to use chemical cues to ascertain predator presence and assess predation risk could be crucial for species nesting in cavities, that is, habitats where visual detection of predators is not easy (Amo et al. 2008). This has recently been tested for hole-nesting songbirds (e.g. Godard et al. 2007; Amo et al. 2008; Roth et al. 2008; Amo et al. 2011) with positive and negative results. In fact, three of these studies showed that songbird species detected predator odours and showed anti-predator behaviour to cope with the risk of predation (Amo et al. 2008, 2011; Roth et al. 2008), whereas the last one showed that the presence of chemical cues of nest predators does not ultimately influence selection of nest site by eastern bluebird (Sialia sialis) (Godard et al. 2007). However, to the best of our knowledge, the use of chemical cues to detect predators has never been investigated in procellariid seabirds.

To fill this gap, we experimentally tested whether the wedge-tailed shearwater (Puffinus pacificus) could detect and respond to the odour of the ship rat. Experiments were conducted in the southern lagoon of New Caledonia, which hosts what is probably one of the world's largest colonies of P. pacificus (Benoit \& Bretagnolle 2002). The ship rat can dramatically reduce the breeding success of $P$. pacificus, as documented on two Hawaiian islands, where the breeding success of birds sharply increased following rat eradication (Smith et al. 2006; Marie et al. 2014).

\section{METHODS}

\section{Study system}

This study was conducted on breeding colonies of P. pacificus on three islets off Isle of Pines $\left(22^{\circ} 37^{\prime} \mathrm{S}\right.$, $167^{\circ} 29^{\prime} \mathrm{E}$ ), New Caledonia (South Pacific Ocean) in 2012. These islets, hereafter called islets $\mathrm{A}, \mathrm{B}$ and $\mathrm{C}$, are protected areas with restricted access for non-scientific activities. Their surface areas are respectively 33.6, 10.0 and 19.3 ha. The islets are formed of uplifted coral blocks, with typical coastal forest on limestone substrate and sandy beaches housing shearwater colonies. Tests were performed between 11 November and 6 December, that is, the period when $P$. pacificus returns to the colonies searching for mates, refurbishing existing burrows or digging new ones. We hypothesized that birds are particularly sensitive to predators' odours at this crucial stage of the breeding cycle. Puffinus pacificus weigh an average of $389 \pm 31 \mathrm{~g}(N=113$, Brooke 2004), spend most of their lives at sea, with intermittent returns to the islands during the breeding period (October to April).

The ship rat was introduced into New Caledonia by European settlers around 1850, whereas the smaller Pacific rat was introduced into New Caledonia much earlier, about 3000 years ago by Melanesian colonizers (Pascal et al. 2006). Our study islets A and B hosted the ship rat but were free of the Pacific rat, whereas islet $\mathrm{C}$ was free of the ship rat but hosted the Pacific rat. The presence/absence of the two rat species was confirmed by a total of 700 trap-nights conducted on the islets.

\section{Olfactory experiment setting}

The experiment consisted of a standard binary choice test using a portable Y-maze involving the choice between two exit arms (Grubb 1974; Bonadonna et al. 2003a; Bonadonna \& Nevitt 2004). The Y-maze was built from a single opaque Polyvinyl chloride (PVC) tube $(16 \mathrm{~cm}$ of diameter) divided into three sections (Fig. 1), to avoid any difference between arms that might influence the bird's choice. The start arm had a temporary bird-holding compartment at its entrance.

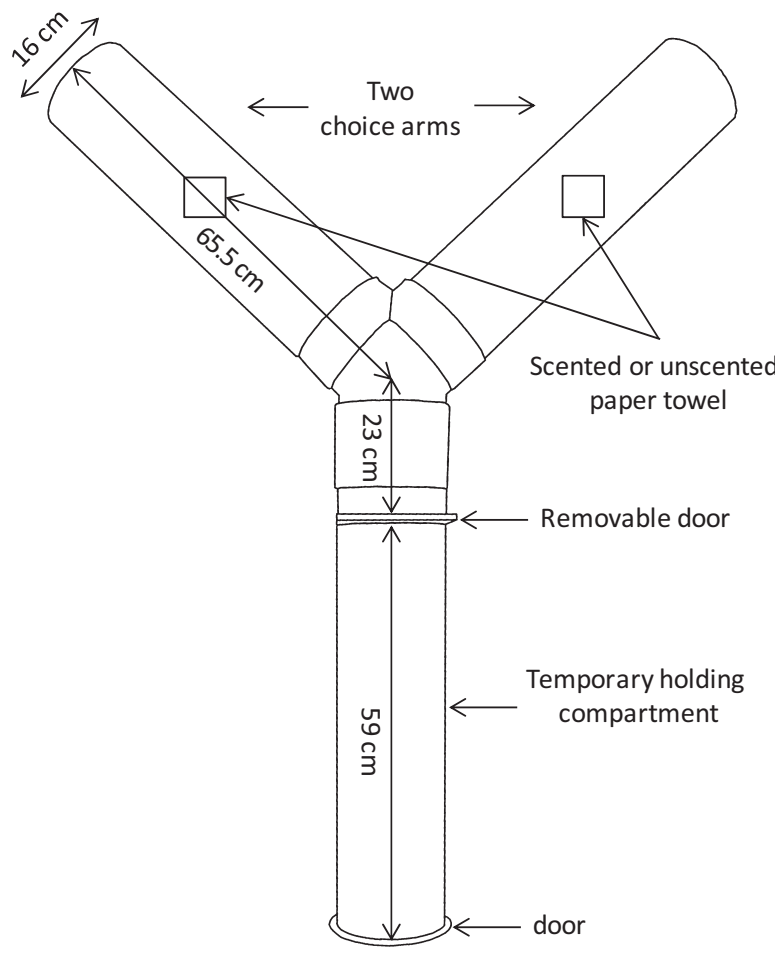

Fig. 1. Diagram of the Y-maze used for experiments. 
The two exit arms each contained a paper towel either scented with ship rat odour (obtained from seven wildtrapped ship rats and by placing paper towels on the floor of cages containing rats to collect urine and faeces) or unscented (soaked with distilled water). To avoid human scent contamination, the paper towels were prepared with latex gloves and handled with metal pliers (one pair of pliers to handle the unscented paper towels and another pair for the paper towels carrying the ship rat odour). For each test, new gloves were used, and the pliers were cleaned with $95 \%$ ethanol. The paper towels were placed on the lower surface of the tube, half way along each exit arm. The bird therefore had to walk over one of the paper towels before leaving the maze. New paper towels, either scented or unscented, were used for each test. The entire maze was cleaned with $95 \%$ ethanol after each test to remove any odour (i.e. rat and shearwater). The same arm contained the ship rat odour in each test, to avoid potential bias due to any presence of residual rat odour (after cleaning) in the arm considered as the control arm. This involved disassembling and interchanging the arms between bird trials so that the odour was sequentially located on the left and on the right, allowing time (about $10 \mathrm{~min}$ ) for the ethanol to evaporate before the next test.

Birds were caught early at night on the ground, when they landed at the colony. There is unfortunately no ringing programme on $P$. pacificus in the study area, so age or reproductive status of individuals (prospecting or breeding bird) could not be determined. Each bird was then placed individually in a new cotton bag (i.e. with no residual odour of other birds), transported to the maze and placed in the holding compartment for a 5-min acclimation period (Bonadonna et al. 2003a,b; Bonadonna \& Nevitt 2004; Bonadonna et al. 2004). The maze was placed outside the colony (approximately $50-100 \mathrm{~m}$ ) to reduce possible interference from birds flying and calling in the vicinity. Both exit arms were oriented toward the edge of the forest habitat, that is, toward a similar dark and uniform area, to avoid a possible visual effect on exit choice. The entrance of the maze faced the sea to avoid (i) the wind entering the two exit arms and potentially intensifying odour diffusion disproportionately in one arm, and (ii) odours from outside entering the two exit arms.

After the trap door was raised, we recorded the bird's choice between scented/control arms to escape the maze. No individual visited the two arms before exiting. Total handling time (from capture to exit) did not exceed $25 \mathrm{~min}$ : $10 \mathrm{~min}$ between capture and acclimation period, $5 \mathrm{~min}$ of acclimation, and 5-10 min to exit the maze. Only a few birds left the maze without prompting. If the bird did not leave the holding compartment after $5 \mathrm{~min}$, we gently knocked on the door to rouse it from its quiescent state and prompt it to move. This procedure has previously been found not to affect birds' choice between two chambers (Amo et al. 2012). In our experiments, no individual left the maze immediately following our 'knocking'; all the birds took time (5-10 min) choosing between the scented and unscented arms before exiting. This indicates that the birds' choice of exit was not affected by prompting, and a response was recorded for all birds tested. As the birds left the experimental device, they were recaught and then released at their initial capture location. Each bird was marked with a dash on the palm of its foot by a permanent marker, so as to avoid birds being tested several times.
Overall, a total of 100 different birds were tested (45 on islet $\mathrm{A}, 15$ on islet $\mathrm{B}$ and 40 on islet $\mathrm{C}$ ). The binary response variable (0: scented arm; 1: unscented arm) was modelled according to the ecological conditions on the islets (a threelevel factor for islets A, B, C), using a generalized linear model with a binomial distribution of error and a logit link (implemented in $\mathrm{R}$ 2.15.0; $\mathrm{R}$ Development Core Team 2012). We assessed whether the bird avoidance rating (proportion of birds choosing the unscented/control arm) differed from a random choice (intercept fixed at 50\%). A power analysis, based on a binomial process with a threshold set at $80 \%$, indicated an avoidance rating of $0.65,0.70$ and 0.72 respectively for a sample size of 100,60 and 40 .

\section{RESULTS}

For each islet, the number of choices of right arm versus left arm showed no lateral preference $(P>0.46)$.

Selection by $P$. pacificus of rat-scented/unscented arms to exit the plastic Y-maze did not differ from random (Fig. 2; Table 1). On islet A, 23 out of 45 birds left through the unscented arm, 7 out of 15 on islet $B$, and 23 out of 40 on islet C. Pooling the islets with ship rats (A and B) versus the islet without ship rats (islet $\mathrm{C}$ ) gave a similar result (Table 1 ). The avoidance rate was therefore very close to $50 \%$ whatever the islet (51\%, $47 \%$ and $57 \%$ respectively for islets $\mathrm{A}, \mathrm{B}$ and C), and irrespective of the presence or absence of the ship rat (50\% for islets $\mathrm{A}$ and $\mathrm{B}$ with ship rats present and 57\% for islet $\mathrm{C}$ with no ship rats).

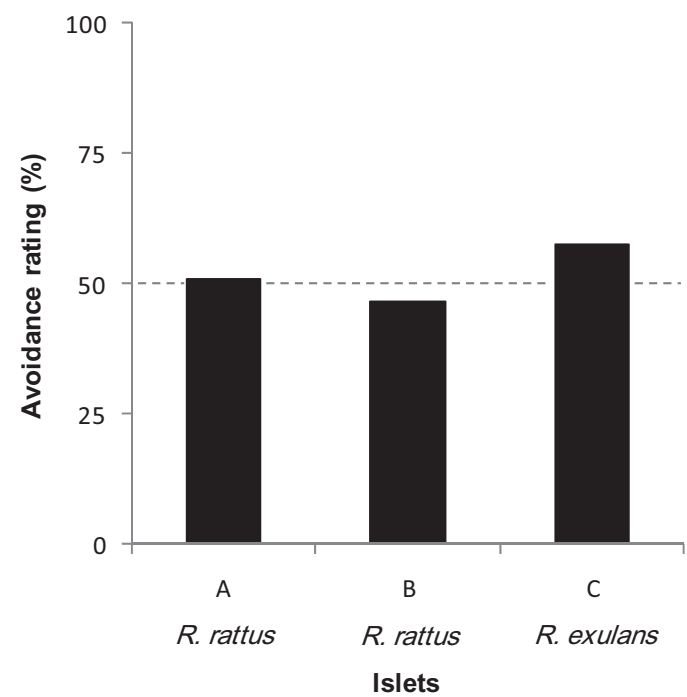

Fig. 2. Avoidance rating (i.e. number of unscented arm choices divided by total number of arm choices) of birds for arm treated with predator (Rattus rattus) odour on the three islets of Isle of Pines Archipelago (New Caledonia). The dotted line indicates the rating fixed for no effect of odour, $50 \%$. The species of rat present on the islets is indicated under $\mathrm{A}, \mathrm{B}$ and $\mathrm{C}$. 
Table 1. Results of generalized linear model for avoidance rating of arm treated with predator odour as compared with no effect of odour (avoidance rating $50 \%$ ) for the three islets and for the two islets with ship rats (i.e. invaded) and the islet without ship rats (i.e. non-invaded)

\begin{tabular}{|c|c|c|c|c|}
\hline & Estimate & $\begin{array}{l}\text { Standard } \\
\text { error }\end{array}$ & $\mathrm{z}$ value & $\begin{array}{c}\operatorname{Pr} \\
(>|z|)\end{array}$ \\
\hline Islet $\mathrm{A}$ & 0.04 & 0.30 & 0.15 & 0.88 \\
\hline Islet $\mathrm{B}$ & -0.13 & 0.52 & -0.26 & 0.80 \\
\hline Islet C & 0.30 & 0.32 & 0.94 & 0.34 \\
\hline Invaded $(\mathrm{A}+\mathrm{B})$ & 0.00 & 0.26 & 0.00 & 1.00 \\
\hline Non-invaded (C) & 0.30 & 0.32 & 0.94 & 0.34 \\
\hline
\end{tabular}

\section{DISCUSSION}

Our results show that the P. pacificus either did not detect the odour of the ship rat or, if they detected it, did not avoid it. This result holds true irrespective of whether ship rats were present on the islet housing the shearwater colony, and is rather surprising given the high vulnerability of Puffinus spp. to rats, particularly the ship rat (Lock 2006; Smith et al. 2006; Jones et al. 2008; Rando \& Alcover 2008; Spatz et al. 2014). The power analysis indicated that our experimental sample size was adequate to detect a biologically relevant difference.

Even though the possibility that stress following capture impaired the birds' ability to respond to odour cannot entirely be ruled out, great care was taken to avoid this bias. In particular, the experiment was designed to minimize stress for individuals (e.g. short handling time, acclimation period before tests). Moreover, similar experiments testing the odours of partners (Bonadonna \& Nevitt 2004) or nests (Bonadonna et al. 2003a,b; Bonadonna et al. 2004) have been successfully conducted on other procellariid seabirds (Antarctic prion Pachyptila desolata, common diving petrel Pelecanoides urinatrix, South-Georgian diving petrel P. georgicus, blue petrel Halobaena caerulea). These studies showed evidences for nestand partner-odour recognition in procellariid seabirds, which provide an olfactory signature that allows birds to recognize their own burrow. We can therefore be reasonably confident that our results actually reveal that $P$. pacificus can detect but do not avoid the odour of ship rats in our study area.

This absence of avoidance is counter-intuitive, especially in light of the extensive use of olfaction in procellariid seabirds for various purposes (Warham 1996). Although the use of olfaction to assess predation risk has never been tested in procellariid seabirds, recent studies with hole-nesting songbirds have shown some evidence of variation in the ability to detect predators between closely related species (Johnson et al. 2011). Naïve great tits (Parus major) (i.e. main- tained in captivity for 10 days after hatching and without predation events or signs of predator visits to nest boxes containing nestlings during the first 10 days of their life) avoided the odour of predators when selecting cavities for roosting (Amo et al. 2011). However, eastern bluebirds (Sialia sialis), which had evolved with snakes and small mammal predators, were as likely to lay eggs in boxes with predator cues as in boxes with neutral cues (Godard et al. 2007); and house wrens (Troglodytes aedon), another species which had co-evolved with nest predators, either did not detect or did not respond to nest predator odour (Johnson et al. 2011). Two native bird species from New Zealand, the rifleman (Acanthisitta chloris) and the South Island robin (Petroica australis), which had not co-evolved with any mammalian predators, did not change their behaviour at nests when the odour of the ship rat (also an introduced predator in New Zealand) was present. In the same study area, only one of the two introduced European passerines, which had co-evolved with mammalian predators, altered their behaviour to minimize risk to themselves (Stanbury \& Briskie 2015). In our study, the lack of co-evolution with mammalian predators combined with the presence of two different introduced rat species, respectively for about 3000 and 150 years, apparently did not lead to development of, or variation in, anti-predator behaviour in $P$. pacificus.

Following the introduction of a new predator in an ecosystem, it has been shown that some species of amphibians and mammals can rapidly develop antipredator responses (Kiesecker \& Blaustein 1997; Russell \& Banks 2007). Regarding birds, one study showed that the New Zealand bellbird (Anthornis melanura) was able to respond to nest predation risk after a co-existence of about 700 years with introduced predators (i.e. mustelids, rats, cats, possums, hedgehogs) (Massaro et al. 2008). No data are available on the time that seabirds need to adapt their behaviour, and the about 150 years of co-existence between shearwaters and ship rats in our system may not be long enough to induce behavioural adaptations. The presence of a predator archetype (i.e. predator species that use similar morphological and behavioural adaptations in obtaining prey) might favour an antipredator response from island prey (Cox \& Lima 2006). Here, however, the roughly 3000 -year presence of the Pacific rat, belonging to the same predator archetype as the ship rat and having similar effects on seabirds weighing $<300 \mathrm{~g}$ (Towns 2009), did not prepare shearwaters to avoid the odour of the ship rat.

Procellariiforms such as P. pacificus are highly philopatric and highly faithful to their breeding site (Warham 1990). These birds form long-term pair bonds, and site fidelity constitutes a means for pairs to reunite (Bried et al. 2003). These biological character- 
istics may thus strongly constrain breeding site selection and encourage birds to come to breed on the same sites, despite the detection and presence of rats.

Shearwaters may also rely on cues other than smell to ascertain the presence of ship rats. These birds could use visual cues (i.e. direct encounters with rats) to assess the risks of nesting in a colony. Another cue might be conspecific reproductive success (Danchin et al. 1998). The long-lived shearwaters typically spend their first 3-5 years as non-breeders but regularly prospect colonies, and in so doing are able to assess average breeding success in different colonies so as to choose the most successful breeding site (Warham 1990, 1996; Danchin et al. 1998). Breeding site selection based on an integrative cue such as conspecific reproductive success is likely to be more efficient than direct cues of the presence of predators.

All these factors may well explain the absence of avoidance of the ship rat odour; yet, some observations had led us to believe that $P$. pacificus would respond. In fact, the dramatic increase in some shearwaters' breeding population immediately following rat eradication (Bourgeois et al. 2013; Marie et al. 2014; VanderWerf et al. 2014) suggested that procellariid seabirds may select their breeding sites according to direct cues. However, we hypothesized that this selection could also be at least partially driven by olfaction (avoidance of burrows 'smelling' of rats), with a predation risk assessment based upon predator chemical cues. Moreover, there is growing evidence that some shearwater species select breeding areas based on the absence of introduced predators, like ship rats, at different spatial scales (Bourgeois \& Vidal 2007; Ruffino et al. 2008, 2009). For example, at the nest scale, the yelkouan shearwater (Puffinus yelkouan) avoids cavities frequented by rats and preferentially selects the deepest and most winding cavities for breeding (Bourgeois \& Vidal 2007; Ruffino et al. 2008). At the colony scale, selection of intra-island refuges (e.g. steep cliffs) less accessible to mammal predators could also partly explain the surprising length of apparent coexistence (about 2000 years) between procellariid seabirds and invasive ship rats on Mediterranean islands (Ruffino et al. 2009).

Although Smith et al. (2006) has shown that the ship rat could dramatically reduce the breeding success of $P$. pacificus, we suspect that for our three studied New Caledonian islets, the impact (i.e. the level of predation on eggs or chicks) of the ship rat may not actually be great enough to induce avoidance behaviour. In fact, if the costs of antipredator responses do not outweigh the benefits, natural selection may not favour the detection of predator chemical cues, nor favour individuals that respond to this odour (Amo et al. 2011). The limited impact of ship rats may be explained by the presence of alternative food resources or may reflect the process by which these predators were introduced. On islands, rats are likely to be introduced in an isolated manner, a few individuals at a time, which may result in a population that does not necessarily impact seabirds. Rat density (Igual et al. 2006) and factors intrinsic to rats such as physical-limiting factors (Freeman \& Lemen 2008; Williams et al. 2009; Zarzoso-Lacoste et al. 2011), lack of predation skill or social learning (Grant et al. 1981; Booth et al. 1996) can alter the magnitude of rat impact on seabirds. Therefore, further experiments should be conducted on a variety of procellariid seabirds, prospecting or breeding birds, and within colonies where the impact of rats is quantified, to determine to what extent ecological factors, bird species characteristics (e.g. body mass, egg size; Bradley \& Marzluff 2003; Jones et al. 2008; Towns 2009), reproductive status of individuals and intensity of predator's impact influence the onset of anti-predator behaviour in procellariid seabirds.

\section{ACKNOWLEDGEMENTS}

We thank the traditional and civil authorities of Isle of Pines and Province Sud for allowing us access to the field sites. We are grateful to $\mathrm{H}$. Kouate, E. Muret and L. Debar, for their help in the field, to K. Bourgeois for its scientific advice and to M. Sweetko for English language revision. A.G. was funded by a Ph.D. scholarship from the École Doctorale Sciences de l'Environnement EDSE251. Additional funds were provided by Province Sud (DENV). We thank the two anonymous reviewers and editor for constructive comments on a draft of this manuscript. The experiments comply with the current laws of France and New Caledonia (permission for sampling protocol $\mathrm{n}^{\circ} 2155$ 2012/ARR/DENV).

\section{REFERENCES}

Amo L., Galvan I., Tomas G. \& Sanz J. J. (2008) Predator odour recognition and avoidance in a songbird. Funct. Ecol. 22, 289-93.

Amo L., Lopez-Rull I., Pagan I. \& Garcia C. M. (2012) Male quality and conspecific scent preferences in the house finch, Carpodacus mexicanus. Anim. Behav. 84, 1483-9.

Amo L., Visser M. E. \& van Oers K. (2011) Smelling out predators is innate in birds. Ardea 99, 177-84.

Atkinson I. A. E. (1985) The spread of commensal species of Rattus to oceanic islands and their effects on island avifaunas. ICPB Tech. Publ. 3, 35-81.

Benoit P. B. \& Bretagnolle V. (2002) Seabirds of the southern lagoon of New Caledonia; distribution, abundance and threats. Waterbird Soc. 25, 202-13. 
Bonadonna F., Cunningham G. B., Jouventin P., Hesters F. \& Nevitt G. A. (2003a) Evidence for nest-odour recognition in two species of diving petrel. F. Exp. Biol. 206, 3719-22.

Bonadonna F., Hesters F. \& Jouventin P. (2003b) Scent of a nest: discrimination of own-nest odours in Antarctic prions, Pachyptila desolata. Behav. Ecol. Sociobiol. 54, 174-8.

Bonadonna F. \& Mardon J. (2013) Besides colours and songs, odour is the new black of avian communication. Chem. Signals Vertebr. 12, 325-39.

Bonadonna F. \& Nevitt G. A. (2004) Partner-specific odor recognition in an Antarctic seabird. Science 306, 835.

Bonadonna F., Villafane M., Bajzak C. \& Jouventin P. (2004) Recognition of burrow's olfactory signature in blue petrels, Halobaena caerulea: an efficient discrimination mechanism in the dark. Anim. Behav. 67, 893-8.

Booth A. M., Minot E. O., Fordham R. A. \& Innes J. G. (1996) Kiore (Rattus exulans) predation on the eggs of the Little Shearwater (Puffinus assimilis haurakiensis). Notornis 43, 147-53.

Bourgeois K., Ouni R., Pascal M., Dromzee S. \& Fourcy D. \& Abiadh A. (2013) Dramatic increase in the Zembretta Yelkouan shearwater breeding population following ship rat eradication spurs interest in managing a 1500-year old invasion. Biol. Inv. 15, 475-82.

Bourgeois K. \& Vidal E. (2007) Yelkouan shearwater nest-cavity selection and breeding success. Cr. Biol. 330, 205-14.

Bradley J. E. \& Marzluff J. M. (2003) Rodents as nest predators: influence on predatory behavior and consequences to nesting birds. Auk 120, 1180-7.

Bried J., Pontier D. \& Jouventin P. (2003) Mate fidelity in monogamous birds: a re-examination of the Procellariiformes. Anim. Behav. 65, 235-46.

Brooke M. (2004) Albatrosses and Petrels across the World. Oxford University Press, New York.

Carthey A. J. R. \& Banks P. B. (2014) Naïveté in novel ecological interactions: lessons from theory and experimental evidence. Biol. Rev. 89, 932-49. doi: 10.1111/brv.12087

Catry P., Silva M. C., MacKay S. et al. (2007) Can thin-billed prions Pachyptila belcheri breed successfully on an island with introduced rats, mice and cats? The case of New Island, Falkland Islands. Polar Biol. 30, 291-394.

Courchamp F., Chapuis J. L. \& Pascal M. (2003) Mammal invaders on islands: impact, control and control impact. Biol. Rev. 78, 347-83.

Cox J. G. \& Lima S. L. (2006) Naivete and an aquatic-terrestrial dichotomy in the effects of introduced predators. Trends Ecol. Evol. 21, 674-80.

Danchin E., Boulinier T. \& Massot M. (1998) Conspecific reproductive success and breeding habitat selection: implications for the study of coloniality. Ecology 79, 241528

Freeman P. W. \& Lemen C. A. (2008) Measuring bite force in small mammals with a piezo-resistive sensor. f. Mammal. 89, 513-17.

Godard R. D., Bowers B. B. \& Wilson C. M. (2007) Eastern bluebirds Sialia sialis do not avoid nest boxes with chemical cues from two common nest predators. F. Avian. Biol. 38, 128-31.

Grant G. S., Pettit T. N. \& Whittow G. C. (1981) Rat predation on Bonin petrel eggs on Midway atoll. F. Field Ornithol. 52, 336-8.

Grubb T. C. (1974) Olfactory navigation to the nesting burrow in Leach's petrel (Oceanodroma leucorrhoa). Anim. Behav. 22, 192-202.
Hervias S., Henriques A., Oliveira N. et al. (2013) Studying the effects of multiple invasive mammals on Cory's shearwater nest survival. Biol. Inv. 15, 143-55.

Igual J. M., Forero M. G., Gomez T., Orueta J. F. \& Oro D. (2006) Rat control and breeding performance in Cory's shearwater (Calonectris diomedea): effects of poisoning effort and habitat features. Anim. Conserv. 9, 59-65.

Johnson L. S., Murphy S. M. \& Parrish G. W. (2011) Lack of predator-odor detection and avoidance by a songbird, the House Wren. F. Field. Ornithol. 82, 150-7.

Jones H. P., Tershy B. R., Zavaleta E. S. et al. (2008) Severity of the effects of invasive rats on seabirds: a global review. Conserv. Biol. 22, 16-26.

Kats L. B. \& Dill L. M. (1998) The scent of death: chemosensory assessment of predation risk by prey animals. Ecoscience $\mathbf{5}$, 361-94.

Kiesecker J. M. \& Blaustein A. R. (1997) Population differences in responses of red-legged frogs (Rana Aurora) to introduced bullfrogs. Ecology 78, 1752-60.

Lock J. (2006) Eradication of brown rats Rattus norvegicus and black rats Rattus rattus to restore breeding seabird populations on Lundy Island, Devon, England. Conserv. Evid. 3, 111-13.

Marie A., Vanderwerf E. A., Young L. C., Smith D. G., Eijzenga J. \& Lohr M. T. (2014) Response of wedge-tailed shearwaters (Puffinus pacificus) to eradication of black rats (Rattus rattus) from Moku'auia Island after reinvasion. Pac. Sci. 68, 547-53.

Massaro M., Starling-Windhof A., Briskie J. V. \& Martin T. E. (2008) Introduced mammalian predators induce behavioural changes in parental care in an endemic New Zealand Bird. PLoS ONE 3, e2331.

Nevitt G. A. (2000) Olfactory foraging by Antarctic procellariiform seabirds: life at high Reynolds numbers. Biol. Bull. 198, 245-53.

Nevitt G. A. \& Bonadonna F. (2005) Seeing the world through the nose of a bird: new developments in the sensory ecology of procellariiform seabirds. Mar. Ecol. Prog. Ser. 287, $292-5$.

Owens I. P. F. \& Bennett P. M. (2000) Ecological basis of extinction risk in birds: habitat loss versus human persecution and introduced predators. Proc. Natl. Acad. Sci. U.S.A. 97, 12144-8.

Pascal M., Barré N., De Garine-Wichatitsky M. et al. (2006) Les peuplements néo-calédoniens de vertébrés: invasions, disparitions. In: Les Espèces Envahissantes Dans L'archipel Néo-Calédonien: Un Risque Environnemental et Économique Majeur (eds M. L. Beauvais, A. Coleno \& H. Jourdan) pp. 116-67. Collection Expertise Collégiale, IRD Editions, Paris.

Quillfeldt P., Schenk I., McGill R. A. R. et al. (2008) Introduced mammals coexist with seabirds at New Island, Falklands: abundance, habitat preferences and stable isotope analysis of diet. Polar Biol. 31, 333-49.

R Development Core Team (2012) R: A Language and Environment for Statistical Computing. R Foundation for Statistical Computing, Vienna, Austria. ISBN 3-900051-07-0, Available from URL: http://www.R-project.org

Rando J. C. \& Alcover J. A. (2008) Evidence for a second western Palaearctic seabird extinction during the last millennium: the lava shearwater Puffinus olsoni. Ibis 150, 188-92.

Rayner M. J., Hauber M. E., Imber M. J., Stamp R. K. \& Klout M. N. (2007) Spatial heterogeneity of mesopredator release within an oceanic island system. Proc. Natl.Acad. Sci. U.S.A. 104, 20862-5. 
Roth T. C., Cox J. G. \& Lima S. L. (2008) Can foraging birds assess predation risk by scent? Anim. Behav. 76, 2021-7.

Ruffino L., Bourgeois K., Vidal E., Icard J., Torre F. \& Legrand J. (2008) Introduced predators and cavity-nesting seabirds: unexpected low level of interaction at breeding sites. Can. F. Zool. 86, 1068-73.

Ruffino L., Bourgeois K., Vidal E. et al. (2009) Invasive rats and seabirds after 2,000 years of an unwanted coexistence on Mediterranean islands. Biol. Inv. 11, 1631-51.

Russell B. G. \& Banks P. B. (2007) Do Australian small mammals respond to native and introduced predator odours? Austral Ecol. 32, 277-86.

Shiels A. B., Pitt W. C., Sugihara R. T. \& Witmer G. W. (2014) Biology and impacts of Pacific Island invasive species. 11. Rattus rattus, the black rat (Rodentia: Muridae). Pac. Sci. 68, 145-84.

Smith D. G., Shiinoki E. K. \& VanderWerf E. A. (2006) Recovery of native species following rat eradication on Mokolici Island, O'ahu, Hawai'i. Pac. Sci. 60, 299-303.

Spatz D. R., Newton K. M., Heinz R. et al. (2014) The biogeography of globally threatened seabirds and island conservation opportunities. Conserv. Biol. 28, 1282-90. doi: 10.1111/cobi.12279

Stanbury M. \& Briskie V. (2015) I smell a rat: can New Zealand birds recognize the odor of an invasive mammalian predator? Curr. Zool. 61, 34-41.
Steiger S. S., Fidler A. E., Valcu M. \& Kempenaers B. (2008) Avian olfactory receptor gene repertoires: evidence for a well-developed sense of smell in birds? P. Roy. Soc. B-Biol. Sci. 275, 2309-17.

Towns D. R. (2009) Eradications as reverse invasions: lessons from Pacific rat (Rattus exulans) removals on New Zealand islands. Biol. Inv. 11, 1719-33.

Towns D. R., Atkinson I. A. E. \& Daugherty C. H. (2006) Have the harmful effects of introduced rats on islands been exaggerated? Biol. Inv. 8, 863-91.

VanderWerf E. A., Young L. C., Crow S. E. et al. (2014) Increase in wedge-tailed shearwaters and changes in soil nutrients following removal of alien mammalian predators and nitrogen-fixing plants at Kaena Point, Hawaii. Restor. Ecol. 22, 676-84. doi: 10.1111/rec. 12126

Warham J. (1990) The Petrels: Their Ecology and Breeding Systems. Academic Press, London.

Warham J. (1996) The Behaviour, Population Biology and Physiology of the Petrels. Academic Press, London.

Williams S. H., Peiffer E. \& Ford S. (2009) Gape and bite force in the rodents Onychomys leucogaster and Peromyscus maniculatus: does jaw-muscle anatomy predict performance? F. Morphol. 270, 1338-47.

Zarzoso-Lacoste D., Ruffino L. \& Vidal E. (2011) Limited predatory capacity of introduced black rats on bird eggs: an experimental approach. F. Zool. 285, 188-93. 